\title{
Does unemployment matter? Economic insecurity, labour market policies and the far-right vote in Europe
}

Article

Accepted Version

Vlandas, T. and Halikiopoulou, D. (2019) Does unemployment matter? Economic insecurity, labour market policies and the far-right vote in Europe. European Political Science, 18 (3). pp. 421-438. ISSN 1680-4333 doi: https://doi.org/10.1057/s41304018-0161-z Available at https://centaur.reading.ac.uk/74766/

It is advisable to refer to the publisher's version if you intend to cite from the work. See Guidance on citing.

To link to this article DOI: http://dx.doi.org/10.1057/s41304-018-0161-z

Publisher: Springer

All outputs in CentAUR are protected by Intellectual Property Rights law, including copyright law. Copyright and IPR is retained by the creators or other copyright holders. Terms and conditions for use of this material are defined in the End User Agreement.

$\underline{\text { www.reading.ac.uk/centaur }}$ 
Central Archive at the University of Reading

Reading's research outputs online 


\title{
Does unemployment matter? Economic insecurity, labour market policies and the far right vote in Europe
}

\section{Tim Vlandas and Daphne Halikiopoulou}

***Accepted for publication in European Political Science in January 2018. This is the pre-proofed accepted version to be published in the special issue entitled Comparing and reconceptualising the Populist Radical Right

\begin{abstract}
What is the impact of unemployment on far-right party support? This article develops a framework that links unemployment to far-right party support, while taking into account both the heterogeneity of the workforce and the role of labour market policies. More specifically we focus on unemployment as a driver of economic insecurity and examine its effect on outsider and insider labour market groups. We identify the extent to which two labour market policies -unemployment benefits and Employment Protection Legislation (EPL) - mediate the effect of unemployment on economic insecurity, thus limiting the impact of unemployment on far right party support. We carry out a large $\mathrm{N}$ analysis on a sample of 14 Western and 10 Eastern European countries between 1991 and 2013. We find that unemployment only leads to higher far-right support when benefits replacement rates are low. The results with regards to the mediating effect of EPL are more complex as EPL only mediates the impact of unemployment when we take into account the share of foreign - born population in the country.
\end{abstract}

Keywords: far right; unemployment; economic insecurity; labour market policies; Europe. 
Word count: 6,177 words.

\section{Introduction}

Most theories that focus on the role the economy plays in shaping the far-right vote expect that economic insecurity, in the form of actual or perceived deprivation, is likely to result in the rise of right-wing extremism (Lipset 1960; Arzheimer 2009; Kitschelt and McGann 1995). This could be a protest vote, a punishment of the establishment and the incumbent, or an endorsement of the 'national preference' and priority native access to welfare that far right parties advocate. Because unemployment is a key driver of economic insecurity, it tends to be treated as a proxy for measuring economic insecurity in political economy and voting behaviour literatures (see e.g. Rueda 2007; Chung and Oorschot 2011 and Marx 2014; Arzheimer 2009; Lipset 1960; Inglehart and Norris 2016). The overall expectation is, broadly speaking, that high levels of unemployment are likely to be associated with high levels of far-right party support. But while theoretically we might expect the two to be correlated, empirically this relationship varies according to country and electoral cycle. An examination of national election results and unemployment rates since 2000 (see Figure 1) reveals no discernible pattern. Thus, if unemployment does matter, it matters only in certain ways, and in certain contexts.

Building on existing literature that considers the economic drivers of right-wing extremism (see e.g. Swank and Betz 2003; Kriesi et al 2006) and the role of labour market policies (see e.g Arzheimer 2009; Halikiopoulou and Vlandas 2016), this article focuses on the conditional effect certain labour market policies have on far right party support. Our rationale is that, by mediating the effect of unemployment on economic insecurity, labour market policies limit the impact of unemployment on far 
right party support. Understanding how and which policies have such a mediating effect is crucial in the context of the 2008 European economic crisis and the rise of far right parties across Europe. By focusing on the policy level, our analysis goes beyond the classic demand (voting behaviour) and supply (party and party- system level) framework. While our focus on policies entails that an analysis of supply-side partylevel variables is outside the scope of this paper- and as such we do not focus on the different stances of European far right parties on the economy- our analysis is complemented by other contributions in this symposium, which focus on the party level.

Our starting point is that unemployment affects the economic insecurity of different labour market groups differently (e.g. Rueda 2006; 2007). First, increasing unemployment directly affects 'outsiders', i.e. the unemployed, because they no longer receive an income. Second, it also increases the actual or perceived insecurity of 'insiders', i.e. those in permanent employment, by increasing their fears of losing their job. The insecurity of these two groups is mediated by different labour market policies: the extent to which outsiders suffer financially depends substantially on the generosity of unemployment benefits; and the extent to which insiders fear losing their jobs depends on Employment Protection Legislation (EPL). We derive and test the observable implications of this insight by applying it to the relationship between unemployment and far-right party support.

We proceed in several steps. First, in the theoretical section, we discuss existing approaches which posit a link between unemployment, economic insecurity and far right support. We then review previous literature that shows that greater economic insecurity is linked with votes for the far-right and that labour market policies both limit insecurity and mediate the impact of unemployment on insecurity. Building on 
these insights we expect the effect of higher unemployment on propensity to vote for the far-right to be mediated by labour market policies. Third, we present our analyses of electoral results in national elections in West and Eastern European countries since 1991. We find that unemployment benefit generosity mediates the impact of unemployment. That is, unemployment only leads to higher far-right support when unemployment benefit replacement rates are low. The mediating effects of EPL are not fully consistent with our expectation, however, except when we take into account the share of foreign born population: EPL only mediates the impact of unemployment in the way we would expect when the percentage of foreign born population is low. This is a surprising finding and more work, particularly at the micro level, is required to examine the reasons for this complex mediating effect of EPL.

This article proceeds as follows. In the first two sections we present our theoretical framework concerning the impact of unemployment on far-right party support. Next we classify far-right parties, discuss our data and empirical tests. The fourth section presents the results from an Ordinary Least Squares (OLS) regression analysis reporting robust standard errors clustered by country. The last section concludes with some implications and avenues for future research.

-------Figure 1 about here------

\section{Unemployment and the far-right vote}

Within the context of the increasing electoral success of parties that stress the importance of the 'national preference' across Europe, there is some debate among scholars with regards to whether these parties belong to the same party family, and if 
so what the most appropriate label for describing this party family is, and what this label actually means. Labels range from 'populist radical right' (Mudde 2007), 'radical right' (Norris 2005), 'extreme right' (Carter 2005; Ignazi 2003) and 'far-right' (Halikiopoulou and Vlandas 2015). The far-right classification emphasizes that what these parties have in common is their claim of ownership of the immigration issue and the justification of their entire policy agenda on the basis of nationalism (Halikiopoulou and Vasilopoulou 2016; Halikiopoulou and Vlandas 2016; Vasilopoulou and Halikiopoulou 2015). In this article we choose the term far-right instead of 'extreme', 'populist radical' or 'radical'-the latter being the term used elsewhere in the symposium- because it allows us to examine all parties that claim ownership of nationalism including both 'extreme' and 'radical' variants, i.e. parties that vary in terms of their relationship with democracy, fascism and violence (Mudde 2010; Vasilopoulou and Halikiopoulou 2015; Halikiopoulou and Vasilopoulou 2016). Therefore using this classification allows us to include in our analysis both radical right parties such as the UK Independence Party (UKIP) and the Dutch Freedom Party (PVV) (Halikiopoulou and Vlandas 2016) and extreme right parties such as the Golden Dawn and Jobbik (Halikiopoulou and Vlandas 2016).

The rise of far-right parties across Europe is particularly relevant within the context of the 2008 economic crisis. Previous research suggests we can theorise a link between the economy and right-wing extremism (see e.g. Lipset 1960; Betz 1994; Kitchelt with McGann 1995; Arzheimer 2009; Swank and Betz 2003; Kriesi et al 2006; Hernandez and Kriesi 2015), and expects economic grievances to be an important factor mobilising support (Ivarsflaten 2008). While the various theories differ in the causal mechanisms they posit and the factors they place their emphasis on, economic insecurity is the common denominator. This is typically triggered by an exogenous 
factor such as a recession and/or globalization. Deteriorating economic conditions are thus expected to impact negatively on voters' expectations and/or their socioeconomic status. This could be because of protest and anti-systemic attitudes, and potential linkages made with unfavourable out-group and authoritarian attitudes (Lubbers and Scheepers 2002). Another reason is competition with immigrants and labour market outsiders for jobs, welfare, and more broadly, for access to the collective goods of the state (Wimmer 1997; see also de Koster et al 2012).

The most economically insecure are those who are unemployed or at risk of unemployment. This includes groups on the social periphery most likely to be structurally affected by economic decline such as blue-collar workers, those in manual employment and unskilled workers who compete the most with immigrants for similar positions. These groups are directly exposed to the risk of unemployment and are the most likely losers of socio-economic change, modernization, globalization and de-industrialization (Betz 1994; Kriesi 1999; Rydgren 2007). It also includes certain labour market insiders and middle class groups whose socio-economic status has declined and who perceive their position has worsened in comparison either with their own past or with another social group (e.g. see Lubbers and Scheeppers 2002). These social groups are indirectly exposed to the risk of unemployment. Given the central role of unemployment in understanding and measuring economic insecurity, a broad range of theories in both political economy and voting behaviour tend to treat unemployment as a proxy for economic insecurity (see e.g. Rueda 2007; Arzheimer 2009; Lipset 1960; Inglehart and Norris 2016).

In sum, unemployment is likely to lead to far-right party support because it exacerbates economic insecurity. However, empirically this is open to criticism. Support for far-right parties does not directly correlate with unemployment. Cross- 
national variation in unemployment rates and far-right support do not suggest a strong correlation since 2000 (see Figure 1). This arguably suggests that the association between unemployment and the far-right at the national level is complex and conditional (see e.g. Arzheimer 2009; Swank and Betz 2003; Halikiopoulou and Vlandas 2016). If the economy does matter, it matters only in certain ways, and in certain contexts.

\section{Reconceptualising the effect of unemployment: insecurity and labour market policies}

This article draws on two broad literatures, i.e. political economy (see e.g. Rueda 2007; Chung Oorschot 2011; Marx 2014) and voting behaviour / far right party support (e.g. Arzheimer 2009; Lipset 1960; Inglehart and Norris 2016) which, from very different perspectives, focus on the central role unemployment plays in driving economic insecurity. Following from this, we conceptualise unemployment as one of the key drivers of economic insecurity, and treat it as a proxy for measuring the latter. Our aim in doing so is to identify the specific policy contexts, which may mediate the effect of unemployment on different social groups, and thus indirectly impact on far right party support. Our logic is as follows. Unemployment is one of the key drivers of economic insecurity. In turn economic insecurity is a key driver of far right party support. As such, in order to understand far right party support we should examine the conditions that may mediate or exacerbate the effect of unemployment on economic insecurity.

We focus on the potentially mediating role of two labour market policies: unemployment benefits (replacement rate) and EPL. The choice to focus on these 
specific labour market policies, rather than overall welfare state spending, is driven by both theoretical and methodological considerations. Theoretically, most of the literature in comparative political economy and welfare state policies looking at how institutions affect insecurity and hence preferences, has examined labour market policies. Methodologically, we have better coverage and more relevant data on labour market policies. While there is also data on welfare state spending, the latter is overly aggregated and captures spending on policies that may not address the labour market insecurity that we are focusing on in this paper. There is a long standing welfare state literature which argues that what matters to individuals is entitlement and rights which protects and insures them against certain risks, not spending or other measures of governments' 'efforts' (e.g. Clasen and Siegel, 2007; Esping Andersen 1990).

Focusing on these two more specific labour market policies also allows us to take into account the heterogeneity of the workforce capturing their effect on those who are both directly and indirectly exposed to the risk of unemployment. Specifically, we theorise the mediating effect of these two policies on both labour market outsiders and insiders. We expect the effect on each labour market group to take place through a distinct channel. First, unemployment is costly for those that are unemployed- the outsiders - because they no longer receive a market income. The size of the income loss for workers who become unemployed (the cost of being unemployed) depends on labour market policies since in most European countries those out of work are eligible to claim unemployment benefits that replace some of their previous income (Van Vliet and Caminada, 2012). In countries with generous benefits, the cost of unemployment relative to employment is lower than in countries where unemployment benefit replacement rates are low (see for instance Anderson and Pontusson 2007 and Chung and Van Oorschot 2011). 
This is also consistent with previous research that finds that unemployment benefits under certain circumstances - can influence individuals' support for the far-right. For example, Arzheimer (2009: 272) finds that "a positive effect [of unemployment rates] becomes visible but only in contexts when either levels of immigration or benefits are very low" and that "at high levels of immigration, unemployment benefits reduce the impact of unemployment". Similarly, at the national level, Halikiopoulou and Vlandas (2016) establish that countries with more generous unemployment benefits show ceteris paribus, lower support for far-right parties in European Parliament elections. This channel is represented graphically in the top part of figure 2.

Second, unemployment also has an effect on those who have a job, i.e. for the insiders (Rueda, 2007), because they become more fearful of losing it. But the impact of unemployment on job insecurity is mediated by EPL. Where EPL is high, dismissal regulations are stringent, and an employer is - everything else being equal - less willing to dismiss an employee when economic activity falls because the cost of firing someone is higher. Consistent with this expectation, then, workers in permanent contracts that are protected by EPL versus those in temporary contracts that are not, exhibit different degrees of insecurities and different policy preferences (e.g. Rueda 2007; Vlandas 2013; Marx, 2014). For instance, Mau et al (2012: 17) find a "significant interaction between the unemployment rate and the employment protection index $[\ldots]$ indicating that unemployment may indeed go along with higher insecurity, but only under conditions of relatively weak labour market regulation." Where it is easy to dismiss them, permanent workers will therefore respond much more fearfully to a rise in unemployment (for more on the effect of EPL on permanent workers, see Rueda 2005 and 2007; Vlandas, 2013). We would therefore expect that an increase in unemployment is more likely to lead to higher support for the far-right 
in countries that have low levels of EPL. This channel is represented in the bottom part of figure 2 .

-------Figure 2 about here------

However, expectations concerning the direct effects of EPL itself on far-right party support are more indeterminate. The labour economics literature shows that EPL not only reduces the probability of losing one's job but also the probability of finding a new job when unemployed (OECD 1994; Bassanini and Duval, 2006; 2009). In principle, it is not clear which of the two effects dominate, and the two may well cancel out each other. A higher EPL may make the employed more secure while making the unemployed more insecure - or vice versa. The average effect of EPL is therefore uncertain. If the effect on workers dominates, unemployment should have a negative effect on far-right party support but if the effect on the unemployed dominates, then the reverse should be true. And if both effects are equivalent, the association should be statistically insignificant.

\section{Data}

We carry out our analysis on a sample that includes 14 West European countries (Austria, Belgium, Denmark, Finland, France, Germany, Greece, Ireland, Italy, Netherlands, Portugal, Spain, Sweden, and the UK) and 10 East European countries (Bulgaria, Czech Republic, Estonia, Hungary, Latvia, Lithuania, Poland, Romania, 
Slovakia and Slovenia). ${ }^{1}$ We focus on national elections that took place in the time period between 1991 and 2013 in order to ensure consistency and comparability. It would be problematic to include a sample from Eastern Europe prior to 1990 because of the communist experience and the differences in political and economic structures that this entails.

We collected data on several variables that allow us to test the observable implications of our theoretical framework while controlling for other demand-andsupply- type factors - such as unemployment, electoral disproportionality and immigration - that have been identified elsewhere (see e.g. Rydgren, 2008; Lucassen and Lubbers, 2012). With respect to our dependent variable, as noted above we use the term 'far-right' as an umbrella term to refer to a range of parties, which we categorise as comparable but not necessarily identical in terms of ideology, origins and organizational structures. While these parties may differ in terms of their association with fascism, the degree to which they accept procedural and substantive democracy and the use of explicit racism in their programmatic agendas (Mudde 2010; Vasilopoulou and Halikiopoulou 2015), they all share ownership of the immigration 'issue' which they typically justify on the basis of nationalism (Hainsworth 2008; Halikiopoulou and Vasilopoulou 2016). In other words, they centre their policy agenda on a presumed need to protect the nation from outsiders and limit the access immigrants have to the nation's collective goods. Our dependent and independent variables, except otherwise indicated, were extracted from the Comparative Political Dataset collected by Armingeon et al, (2013) (as they provide full descriptions and sources we only briefly discuss them here). Our dependent variable - 'far right votes' - was calculated as the sum of the percentage of votes

\footnotetext{
${ }^{1}$ We do not include Croatia due to lack of data for EPL and countries that are not members of the European Union are not included in our analysis.
} 
classified as right populist in Armingeon et al. (2013) database (i.e. the variables right1, right2, right3, right4 and right5) ${ }^{2}$.

Our most important economic variable is the unemployment rate, defined as a percentage of the civilian labour force. But we also include real GDP growth (percent change from previous year) and total trade (sum of exports and imports) as a share of GDP. We expect low and negative growth, and high unemployment, to be positively associated with far right support. In addition, we need data for two sets of labour market policies. The first is unemployment benefits, which we proxy with data by Van Vliet et al_(2012) on net unemployment replacement rate for an average worker (one earner household with two children). The replacement rate captures the percentage of a worker's wage that is 'replaced' by unemployment benefits after becoming unemployed. We expect unemployment benefits to be negatively correlated with far right party support and to limit the impact of unemployment on this support. We supplement the EPL index developed by the OECD with an extension to Central and East European countries collected for this purpose by Avdagic (2016). ${ }^{3}$ This EPL index captures the extent to which the legislation in a given country restricts the ability of employers to dismiss workers on permanent contracts (higher values indicate it is harder for employers to dismiss workers). We have no expectations concerning the average effect of EPL but we expect it to limit the impact of unemployment on far right party support.

We also include the following control variables for political factors. First, we include an index of disproportionality developed by Gallagher (1991) which may reduce

\footnotetext{
${ }^{2}$ We follow the database classification except for the UK where we include UKIP as a far right party in accordance to Immerzeel, et al 2015 and Halikiopoulou and Vlandas 2016 who include this borderline cases in their respective classifications. For more details on how Armingeon et al. (2013) classify parties, see page 43 of their codebook.

${ }^{3}$ We would like to thank Sabina Avdagic for sharing her data with us.
} 
incentives to vote for the far right since they are less likely to gain seats. Since these are national elections, the incumbent party may have an impact on voting behaviour so we include a measure of mainstream right-wing party control of cabinet posts to test whether this makes voting for the far-right more or less likely. Next, we test the impact of voting turnout in national elections and union density. We posit that unions direct the working classes to vote for the left or the far-left and that their decline over time has likely benefited the far-right, but we have no expectations for how voting turnout affects far right party support.

Finally, we include two binary variables. Our crisis dummy takes value 1 if the election took place after 2007 and 0 otherwise while our post-communist dummy takes value 1 if the country has a communist past (Bulgaria, Czech Republic, Estonia, Hungary, Latvia, Lithuania, Poland, Slovakia and Slovenia) and 0 otherwise.

\section{Analysis of National elections}

We use Ordinary Least Square (OLS) to carry out our regression analyses and we report robust standard errors clustered by country, since autocorrelation and heteroscedasticity are likely to be present. Because we are interested in explaining variation across countries, we are reluctant to include country fixed effects which would 'explain away' the cross-national variation we are trying to explain. Indeed, as Plümper et al (2005: 331) argue, "unit dummies completely absorb differences in the level of independent variables across units". Thus, the 'level effect' of our key independent variables (e.g. unemployment, unemployment benefits and EPL) is suppressed when including fixed country effects (ibid: 333). While the effect of a 
change in unemployment and unemployment benefits is also theoretically relevant, our main concern here is about the effect of the level of these variables on far-right support and there is little change in EPL over time. In addition, country fixed effects would be collinear with our dummy variable for post-communist countries and time effects would be collinear with our crisis dummy variable. That being said, we have run a few models with country or time effects in EP elections to investigate how this affects the results ${ }^{4}$ and we have also checked the robustness of our results to the exclusion of country outliers ${ }^{5}$.

The results are shown in Table 1. Column 1 shows that unemployment and EPL have no effect, while unemployment benefits have a statistically significant negative effect. GDP growth, openness, union density, and control of the cabinet by mainstream rightwing parties have no statistically significant effect either. But voter turnout has a positive effect, which suggests that incentivising people to vote is unlikely in itself to stem the rise of the far-right. Column 2 suggests that neither having a Communist past $^{6}$ nor the crisis (i.e. the period after 2007) had an independent effect on support for far-right parties while column 3 provides no support for the notion that higher levels

\footnotetext{
${ }^{4}$ Including country fixed effects or country and time effects does not change the results for columns 1 and 2 in table 1 (except for voter turnout which becomes insignificant with time effects). Note that whenever we include fixed effects Stata automatically drops our post-communist dummy variable as it becomes collinear (and similarly for time effects and our crisis dummy variable). For column 3 of table 1 , union density becomes significant when fixed effects are included (but loses significance again when time effects are added), while trade openness and voter turnout are robust to the inclusion of country effects but not of time effects. The unemployment benefit replacement rate retains significance throughout. Reproducing the results for Figure 3 while including fixed effects results in non-significant results consistent with the notion that the effect we are picking up is cross-national, but running the regression with fixed effects in Figure 4 does not change the results (we cannot re-estimate the Figure 4 with time effects as the latter are collinear with our crisis dummy variable). However, running the regression with fixed effects in Figure 5 results in non-significant results again consistent with the notion that it is the cross-national variation in EPL, not the within country over time variation, that matters.

${ }^{5}$ Excluding countries with very high (e.g. Sweden, Netherlands, France) or very low (e.g. UK, Greece, Poland) values of unemployment benefit does not change key result for unemployment benefit in column 1 of table 1. Similarly, excluding countries with very high (e.g. Austria, Slovakia, Greece) or very low (e.g. Spain, Germany) votes for far right does not change key result for unemployment benefit in column 1 of table 1.

${ }^{6}$ The communist past is captured by dummy variable with value 1 for post-communist countries (Bulgaria, Czech Republic, Estonia, Hungary, Latvia, Lithuania, Poland, Slovakia and Slovenia).
} 
of immigration contribute to an increase in far-right support.

Finally, we examined the interaction between labour market policies and unemployment. A linear interaction term between unemployment and unemployment benefits is statistically significant and shown in Figure 2. Unemployment is only associated with higher far-right party support when unemployment benefits are low. However, the present results for an interaction effect between EPL and unemployment are - at best - mixed. There is no overall linear interaction effect between the two variables (upper left panel of figure 4). When a non-linear ${ }^{7}$ interaction term between EPL, unemployment and the crisis dummy is introduced (only shown in figure in upper right panel of figure 4, not in table since results cannot be directly interpreted from table), unemployment is positively associated with higher levels of support for the far-right only in crisis times and when EPL is either very low or very high (outside of the period 2008-2013, which the crisis dummy captures, there is no mediating effect of EPL). The latter is surprising and seems to be driven by high EPL indices in several of the East European countries (Czech Republic: 3.496; Lithuania 3.365; Slovakia 3.413; Slovenia 3.349).

As a final check on the interaction effects between EPL and unemployment (only shown in figure 5, not in table since results cannot be directly interpreted from table), we also include an interaction between EPL, unemployment and the share of the foreign born population. Figure 5 shows that EPL only mediates the impact of unemployment on far-right party support when there are few foreigners in the country. One possible reason for this is that in countries with a high share of foreigners, insecurity is 'externalised' on foreigners, hence the protective effects of

\footnotetext{
${ }^{7}$ The non-linearity refers to EPL, i.e. in this case the interaction term takes the following form in stata: c.EPL\#\#.EPL\#\# c.Unemployment rate\#\# c.Crisis dummy (thus, the non-linearity is introduced only for EPL).
} 
EPL are not always needed. An alternative explanation is that domestic workers feel insecure when there are many foreigners even in the presence of high EPL. But the results for EPL in this sample at this level of analysis are at best speculative at this stage and more research, particularly at the micro level, is required to investigate the issue further.

-----Table 1 about here-----

----- Figure 3 about here-----

----- Figure 4 about here-----

-----Figure 5 about here-----

\section{Discussion and conclusion}

This article has examined the potential mediating effect of labour market policies on unemployment, and the impact of this effect on far-right party support. Our logic was the following: Unemployment is often understood as one of the key drivers of economic insecurity. In turn economic insecurity is often expected to be a key driver of far-right party support. Therefore policies that mediate the effect of unemployment on economic insecurity are likely to have an indirect impact on far right party support. Distinguishing between the different effect of unemployment on labour market outsiders and insiders, we focused specifically on two labour market policies, i.e. unemployment benefits and EPL, and tested the mediating effects of these policies on a sample of national elections since 1991 in both West and Eastern European countries. 
Our findings specify the interaction between unemployment and labour market policies in the following way. Unemployment is on average not a significant determinant of far-right party support, but it is positively associated with the far-right when unemployment benefits are low. Thus, not only do unemployment benefits have a direct effect on far right party support, they also play an important mediating role. By contrast, EPL appears to have no independent effect on far-right party support, and only mediate the impact of unemployment when the share of foreigners in the country is low.

This article advances the literature on far right party support in four ways. First, by capturing the importance of policies as mediating factors, we go beyond the classic demand and supply framework (Mudde 2007) which assumes that far right party support is either the product of trigger factors, such as economic crisis, which alter the dynamics of demand (see e.g. Lipset 1960; Kriesi et al 2006); or the product of supply-side factors at the party level, for example party competition, the party system and party strategies (see e.g. Carter 2005; Mudde 2010; Koopmans and Statham 1999; Halikiopoulou et al 2013). Our analysis adds a third dimension to this framework and explains why similar demand and supply-side patterns may lead to different outcomes- for example why countries with high levels of unemployment, where far right parties exist and compete in the party system, do not have high levels of far right party support. Showing that far-right party support is fuelled less strongly by national unemployment levels in cases with specific labour market institutional arrangements represents an important step in solving the empirical puzzle of the relationship between unemployment and far-right party support.

Second, we contribute to the debate on whether the economy - and specifically economic grievances- matters at all for far right party support (see e.g. Ivarsflaten 
2008; Lucassen and Lubbers 2012). We show that the limited correlation between unemployment and far right party support observed empirically does not mean that the economy is irrelevant, but rather that the relationship between economic distress and far right party support is complex and conditional on policies. This suggests that at times of economic crisis a crisis-management approach that includes protective social policies is likely to limit far right party support.

Third, we make an important contribution by showing that economic insecurity is not only an argument about the have- nots, i.e. the unemployed and/or the working classes who are directly exposed to unemployment. Rather, it is an argument about the extent to which deteriorating economic conditions may have a negative impact on the expectations and/ or the socio-economic status of both labour market outsiders and insiders, i.e. a broad range of social groups, including the middle classes. Distinguishing between the two conceptually distinct channels through which unemployment imposes costs on the unemployed and increases risks for the employed has not been previously addressed in the far right literature. It is important because it can explain middle class support for far right parties.

Finally, by focusing on labour market policies, we reconcile literatures on political economy and voting behaviour, which both address the relationship between insecurity and far right party support from a different perspective, rarely speaking to each other and often producing conflicting results. By developing a framework that links unemployment and economic insecurity to support for far-right parties while taking into account the heterogeneity of the workforce and the role of labour market policies, we are able to draw conclusions of interdisciplinary value.

Overall, our analysis offers a theoretically innovative answer to the far right puzzle. 
Our findings are not only important in themselves but also open up significant avenues for future research. Micro-level analysis could further specify the labour market circumstances under which particular social groups support the far right. Party-level analysis could elaborate on the theoretical and empirical links between labour market policies and specific far right party strategies. Finally, further research could shed more light on the role of EPL in either exacerbating or containing the insecurity of different social groups; and examine additional labour market policies and the extent to which they have an impact on far right party support. 


\section{References}

Allard, G. (2005a), “Measuring Job Security Over Time: In Search of a Historical Indicator", Instituto de Empressa Working Paper WP-05. (Available from http://www.ie.edu/eng/claustro/claustro_working_papers.asp)

Arzheimer, K. (2009), 'Contextual Factors and the Extreme Right Vote in Western Europe', 1980-2002. American Journal of Political Science, 53, 259-275. doi: 10.1111/j.1540-5907.2009.00369.

Avdagic, Sabina (2016). Causes and Consequences of National Variation in Employment Protection Legislation in Central and Eastern Europe. [Data Collection]. Colchester, Essex: Economic and Social Research Council. 10.5255/UKDA-SN$\underline{850598}$

Bassanini, A. and Duval, R. (2006) 'Employment patterns in OECD countries: Reassessing the role of Policies and Institutions', in labour and social affairs Directorate for employment (ed.), Social, employment and migration working paper (Paris: OECD).

Bassanini, A. and Duval, R. (2009) 'Unemployment, institutions, and reform complementarities: re-assessing the aggregate evidence for OECD countries', Oxford Review of Economic Policy, 25/1: 40-59.

Betz H.-G. (1994) Radical Right-Wing Populism in Western Europe. New York: St. Martin's Press

Carter, E., (2005) The Extreme Right in Western Europe. Manchester University Press, Manchester,

Chung, H. and Van Oorschot, W. (2011) 'Institutions versus market forces: 
Explaining the employment insecurity of European individuals during (the beginning of) the financial crisis' Journal of European Social Policy October 1, 2011 21: 287301.

Clasen, Jochen and Siegel, Nico A. (2007) Investigating Welfare State Change: The 'dependent Variable Problem'. Edward Elgar.

De Koster, W. P. Achterberg and J. van der Waal (2012) 'The new right and the welfare state: The electoral relevance of welfare chauvinism and welfare populism in the Netherlands', International Political Science Review, 34(1): 3-20.

Eatwell R. (2000) 'The rebirth of the extreme right in Western Europe?' Parliamentary Affairs, 53(3): 407-25.

Ennser, L. (2012) 'The homogeneity of West European party families: The radical right in comparative perspective', Party Politics 18: 151.

Esping Andersen, G. (1990) Three world of welfare Capitalism. Princeton University Press: New Jersey.

Hainsworth, P. (2008). The extreme right in Western Europe. Abingdon: Routledge.

Halikiopoulou, D., Nanou, K. and Vasilopoulou, S. (2012) 'The Paradox of Nationalism: The Common Denominator of Radical Right and Radical Left Euroscepticism', European Journal of Political Research, 51(4): 504-539.

Halikiopoulou D, Mock S and Vasilopoulou S (2013) The civic zeitgeist: nationalism and liberal values in the European radical right. Nations and Nationalism 19(1): 107127. 
Halikiopoulou, D. and Vasilopoulou, S., (2016) 'Breaching the social contract: crises of democratic representation and patterns of extreme right party support', Government and Opposition. FirstView, DOI: http://dx.doi.org/10.1017/gov.2015.43

Halikiopoulou D and Vlandas T (2016) 'Risks, costs and labour markets: explaining cross-national patterns of far right party success in European Parliament elections'. Journal of Common Market Studies, doi: 10.1111/jcms.12310.

Hernández, E. And Kriesi, H. (2015), 'The electoral consequences of the financial and economic crisis in Europe'. European Journal of Political Research. doi:

$10.1111 / 1475-6765.12122$

Immerzeel, T., et al (2015) 'Competing with the radical right: Distances between the European radical right and other parties on typical radical right issue's, Party Politics, DOI: $10.1177 / 1354068814567975$

Inglehart, R. and Norris (2016) 'Trump, Brexit, and the Rise of Populism: Economic Have-Nots and Cultural Backlash', Harvard Kennedy School Faculty Research Working Paper Series

Ivarsflaten, E. (2008). 'What unites right-wing populists in Western Europe? Reexamining grievance mobilization models in seven successful cases'. Comparative Political Studies, 41: 3-23.

Kitschelt, H. with McGann, A. (1995) The Radical Right in Western Europe: A Comparative Analysis. Ann Arbor: University of Michigan Press.

Kitschelt, H. (2007) 'Growth and Persistence of the Radical Right in Postindustrial Democracies: Advances and Challenges in Comparative Research', West European 
Politics, 30(5): 1176-1206.

Koopmans, R. and Statham, P. (1999) 'Ethnic and civic conceptions of nationhood and the differential success of the extreme right in Germany and Italy', in Giugni, M. et al. (ed.) How Social Movements Matter. Minneapolis, MN: University of Minnesota Press, pp. 225-51.

Kriesi, H. (1999). 'Movements of the left, movements of the right: Putting the mobilization oftwo new types of social movement into political context'. In H. Kitschelt et al. (eds), Continuity and change in contemporary capitalism. Cambridge: Cambridge University Press.

Kriesi, H., Grande, E., Lachat, R., Dolezal, M., Bornschier, S., Frey, T. (2006) 'Globalisation and transformation of the national political space: Six European countries compared', European Journal of Political Research, 45(6): 921-956.

Lipset SM (1960) Political Man: The Social Bases of Politics. New York: Doubleday Lubbers, M., Gijsberts, M. and Scheepers, P. (2002), 'Extreme right-wing voting in Western Europe' European Journal of Political Research 41: 345-378

Lubbers, M. and Scheepers, P. (2002) 'French Front National Voting: a micro and macro perspective', Ethnic and Racial Studies, 25(1): 120-149.

Lucassen, G. and Lubbers, M. (2012). 'Who Fears What? Explaining Far-Right-Wing Preference in Europe by Distinguishing Perceived Cultural and Economic Ethnic Threats', Comparative Political Studies, 45(5): 547-574.

Mair P and Mudde C (1998) 'The party family and its study'. Annual Review of 
Political Science 1(1): 211-229.

Marx, P. (2014) 'Labour Market Risks and Political Preferences: The Case of

Temporary Employment', European Journal of Political Research, 53(1): 136-159.

Mau, Steffen, Mewes, Jan and Schöneck, Nadine (2012) 'What determines subjective socio-economic insecurity? Context and class in comparative perspective', SocioEconomic Review October 1, 2012 10: 655-682

Minkenberg, M. and Perrineau, P (2004) 'The Radical Right in the European Elections 2004', International Political Science Review, 28(1): 29-55

Mudde, C. (2007) Populist radical right parties in Europe. Cambridge; New York: Cambridge University Press.

Mudde, C. (2010) ‘The Populist Radical Right: A Pathological Normalcy’, West European Politics, 33(6): 1167-1186.

Mughan, A. and Lacy, D. (2002). 'Economic performance, job insecurity and electoral choice', British Journal of Political Science 32(4): 513-533.

OECD, 'Jobs Study', (Paris: OECD, 1994).

Plümper, T., Troeger, V., Manow, P. (2005) 'Panel data analysis in comparative politics: Linking method to theory', European Journal of Political Research 44: 327 354.

Rueda D. (2005) 'Insider-Outsider Politics in Industrialized Democracies: The Challenge to Social Democratic Parties'. American Political Science Review, 99:6174. 
Rueda D. (2006) 'Social Democracy and Active Labour Market Policies: Insiders, Outsiders, and the Politics of Employment Promotion'. British Journal of Political Science, 36:385-406.

Rueda D. (2007) Social Democracy Inside Out. Oxford: Oxford University Press.

Rydgren, J. (2007) 'The Sociology of the Radical Right', The Annual Review of Sociology, 33:241-262.

Rydgren, J. (2008) 'Immigration sceptics, xenophobes or racists? Radical right-wing voting in six West European countries', European Journal of Political Research 47, pp. 737-765,

Scheve Kenneth and Slaughte, Matthew J. (2004) 'Economic Insecurity and the Globalization of Production'. American Journal of Political Science Volume 48, Issue 4, pages 662-674, October 2004.

Sniderman, P., and Hagendoorn, L. (2007). When ways of life collide. Princeton, NJ: Princeton University Press.

Swank, D and Betz, HG. (2003) 'Globalization, the Welfare State and Right-Wing Populism in Western Europe', Socio-Economic Review, 1: 215-245.

Van Vliet, O. and Caminada, K. (2012), 'Unemployment replacement rates dataset among 34 welfare states 1971-2009: An update, extension and modification of Scruggs' Welfare State Entitlements Data Set', NEUJOBS Special Report No. 2, Leiden University

Vasilopoulou, S. and Halikiopoulou, D. (2015) The Golden Dawn's Nationalist 
Solution: Explaining the Rise of the Far Right in Greece, New York: Palgrave. ISBN 9781137487124.

Vlandas, T. (2013) 'The politics of temporary work deregulation in Europe: solving the French puzzle'. Politics and Society, 41 (3): 425-460.

Wimmer, A. (1997). 'Explaining xenophobia and racism: a critical review of current research approaches', Ethnic and Racial Studies, 20(1): 17-41. 
TABLES AND FIGURES

Table 1: Determinants of far right support in national elections of western and eastern European countries since 1991

\begin{tabular}{|c|c|c|c|c|c|}
\hline Column & $(1)$ & (2) & (3) & (4) & (5) \\
\hline \multirow[t]{2}{*}{ Unemployment rate } & 0.06 & 0.02 & 0.09 & $0.75 \mathrm{t}$ & -0.24 \\
\hline & $(0.198)$ & $(0.167)$ & $(0.259)$ & $(0.432)$ & $(0.579)$ \\
\hline \multirow[t]{2}{*}{ EPL } & 0.93 & 0.21 & 1.43 & 0.00 & -0.66 \\
\hline & $(1.761)$ & $(1.525)$ & $(2.672)$ & $(1.505)$ & $(2.628)$ \\
\hline \multirow{2}{*}{$\begin{array}{l}\text { Unemployment benefit } \\
\text { replacement rate }\end{array}$} & $-15.65 * *$ & $-14.41^{*}$ & $-14.80 * *$ & 0.12 & $-14.23^{*}$ \\
\hline & $(5.578)$ & $(5.892)$ & $(5.575)$ & (6.935) & (5.930) \\
\hline \multirow[t]{2}{*}{ Real GDP growth } & -0.15 & -0.13 & -0.33 & -0.08 & -0.13 \\
\hline & $(0.174)$ & $(0.197)$ & $(0.324)$ & $(0.202)$ & $(0.198)$ \\
\hline \multirow[t]{2}{*}{ Trade openness of the economy } & 0.02 & 0.00 & $0.09 *$ & 0.01 & 0.00 \\
\hline & $(0.037)$ & $(0.038)$ & $(0.039)$ & $(0.035)$ & $(0.038)$ \\
\hline \multirow[t]{2}{*}{ Voter turnout in election } & $0.34 * *$ & $0.40 * *$ & $0.43^{*}$ & $0.42^{* * *}$ & $0.40 * * *$ \\
\hline & $(0.115)$ & $(0.124)$ & $(0.176)$ & $(0.128)$ & $(0.116)$ \\
\hline \multirow[t]{2}{*}{ Union density } & -0.02 & -0.01 & 0.05 & -0.01 & -0.00 \\
\hline & $(0.065)$ & $(0.061)$ & $(0.077)$ & $(0.060)$ & $(0.060)$ \\
\hline \multirow{2}{*}{$\begin{array}{l}\text { Gallagher index of } \\
\text { disproportionality }\end{array}$} & 0.22 & 0.21 & $0.39 \mathrm{t}$ & 0.28 & 0.20 \\
\hline & $(0.203)$ & $(0.214)$ & $(0.215)$ & $(0.191)$ & $(0.225)$ \\
\hline \multirow{2}{*}{$\begin{array}{l}\text { Right-wing parties as } \% \text { of total } \\
\text { cabinet posts }\end{array}$} & 0.00 & -0.00 & 0.00 & -0.00 & 0.00 \\
\hline & $(0.024)$ & $(0.025)$ & $(0.038)$ & $(0.025)$ & $(0.025)$ \\
\hline \multirow[t]{2}{*}{ Former post-communist country } & & 6.18 & 1.35 & 6.10 & 6.22 \\
\hline & & $(4.277)$ & $(5.971)$ & $(4.362)$ & $(4.234)$ \\
\hline \multirow[t]{2}{*}{ Crisis dummy } & & 0.91 & 0.46 & 0.87 & 0.87 \\
\hline & & $(2.080)$ & $(3.242)$ & $(2.131)$ & $(2.166)$ \\
\hline $\begin{array}{l}\text { Immigrant inflow on year of } \\
\text { election }\end{array}$ & & & -1.44 & & \\
\hline (\% of recipient population) & & & $(1.286)$ & & \\
\hline Unemployment* & & & & $-1.43 \mathrm{t}$ & \\
\hline \multicolumn{6}{|l|}{$\begin{array}{l}\text { Unemployment benefit } \\
\text { replacement rate }\end{array}$} \\
\hline & & & & $(0.779)$ & \\
\hline \multirow[t]{2}{*}{ Unemployment*EPL } & & & & & 0.11 \\
\hline & & & & & $(0.264)$ \\
\hline \multirow[t]{2}{*}{ Constant } & -13.98 & -18.54 & $-32.49 *$ & $-27.96 * *$ & -16.15 \\
\hline & $(13.358)$ & $(11.600)$ & $(12.874)$ & $(9.578)$ & (10.617) \\
\hline Observations & 98 & 98 & 72 & 98 & 98 \\
\hline Number of countries & 24 & 24 & 19 & 24 & 24 \\
\hline R-squared within model & 0.29 & 0.29 & 0.28 & 0.29 & 0.29 \\
\hline R-squared overall model & 0.11 & 0.15 & 0.23 & 0.18 & 0.16 \\
\hline R-squared between model & 0.06 & 0.11 & 0.17 & 0.14 & 0.12 \\
\hline
\end{tabular}


Figure 1: National election results in Europe since 2000

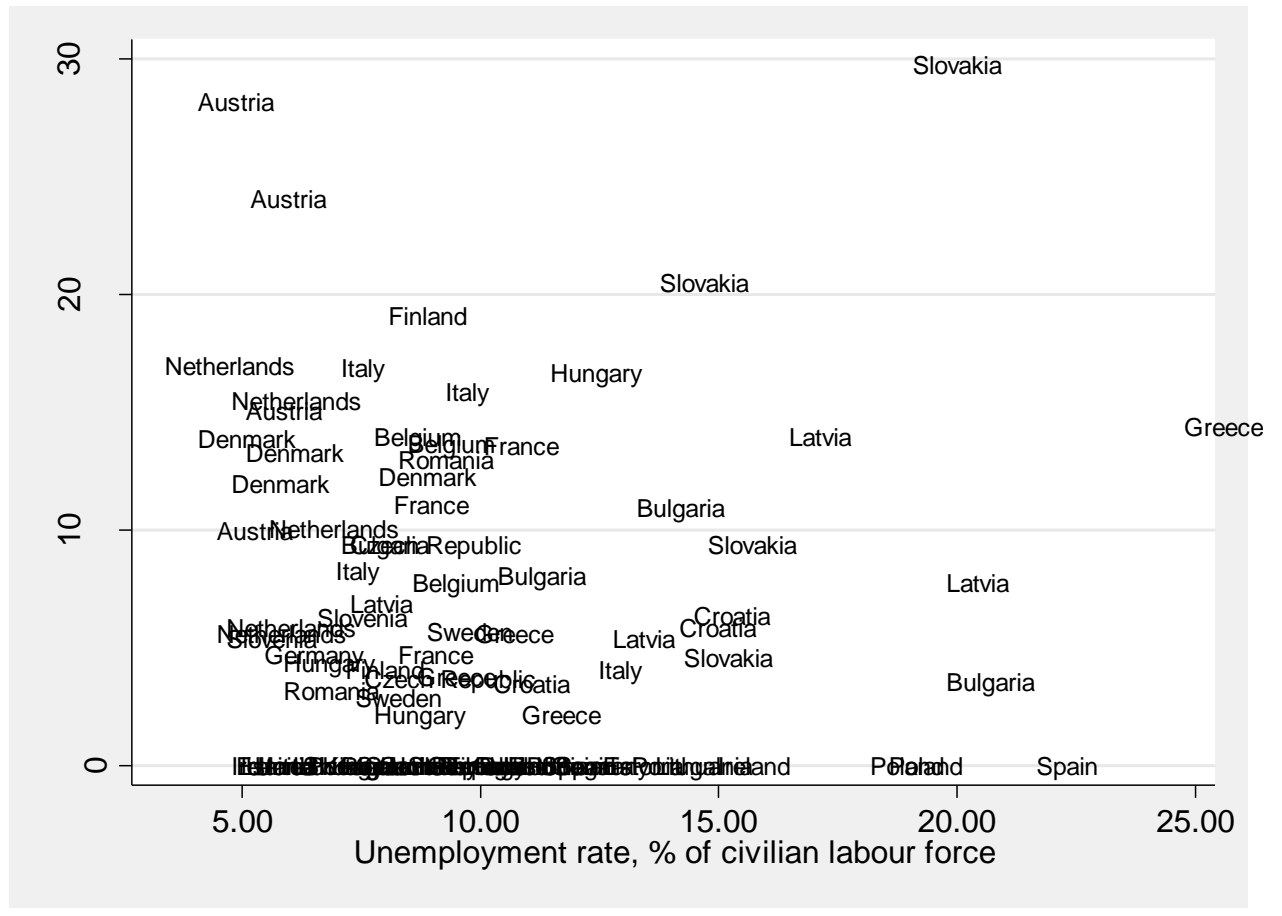

Figure 2: The relationship between unemployment, labour market policies, economic insecurity and far right party support

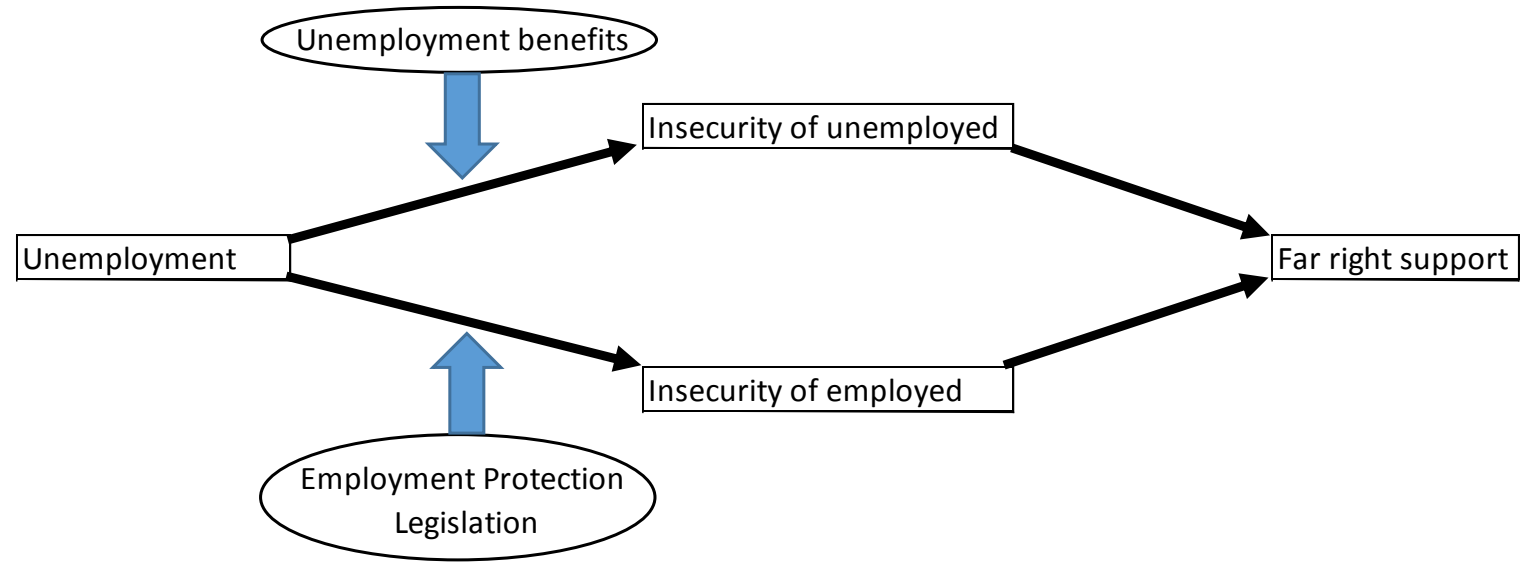


Figure 3: Effect of unemployment on far right party support conditional on unemployment benefits in national elections of western and eastern European countries since 1991

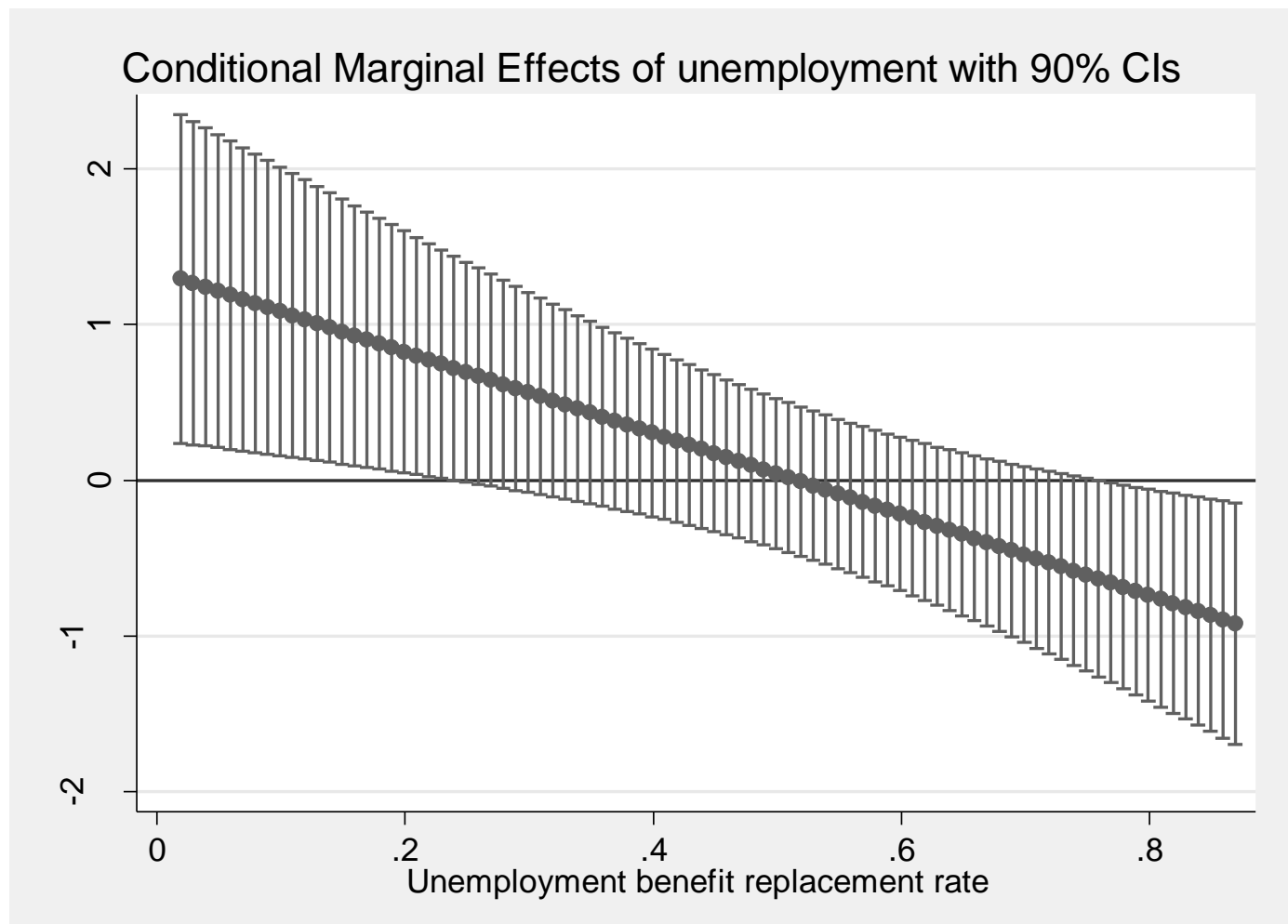


Figure 4: Effect of unemployment on far right party support conditional on EPL in national elections of western and eastern European countries since 1991 (in general and interacted with crisis with non-linear specification)

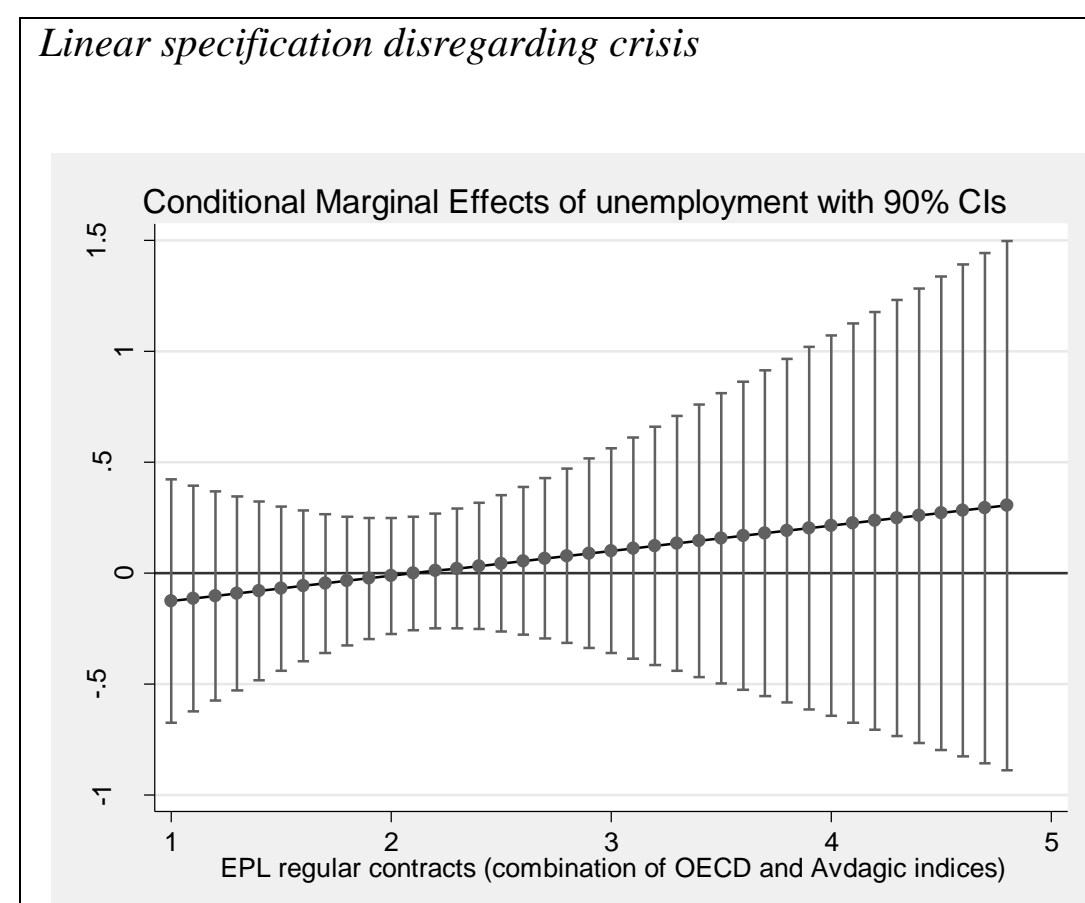

Non-linear specification for crisis (>2007) time

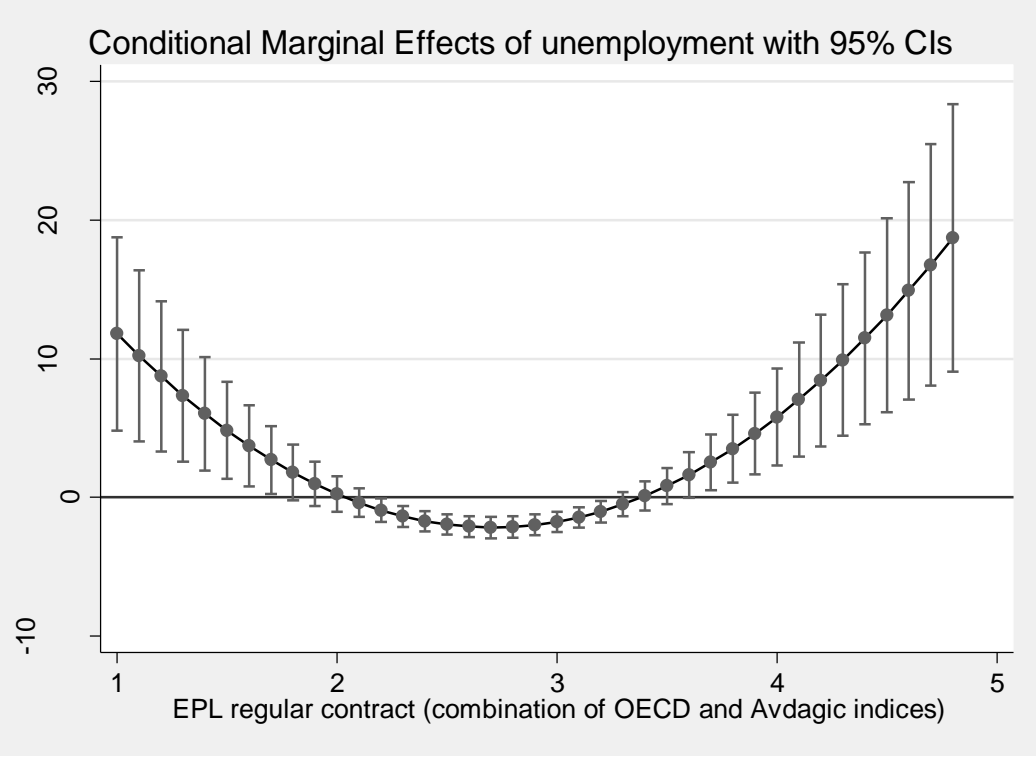




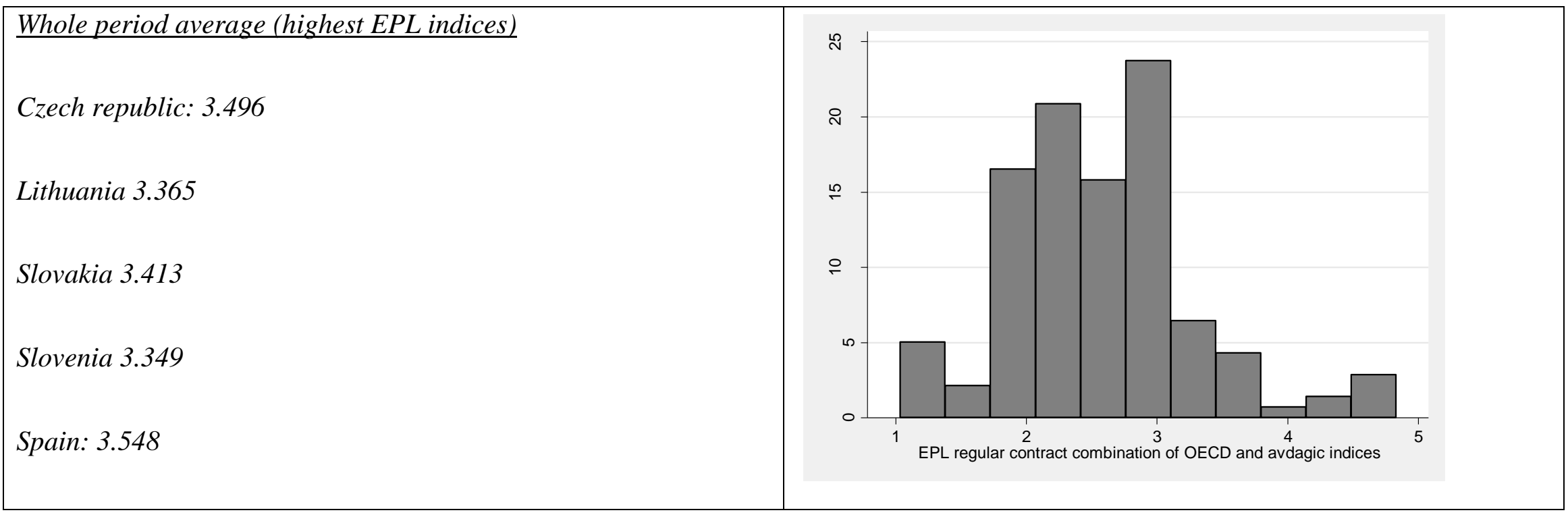


Figure 5: Effect of unemployment on far right party support conditional on EPL and percentage of foreign born population in national elections of western and eastern European countries since 1991

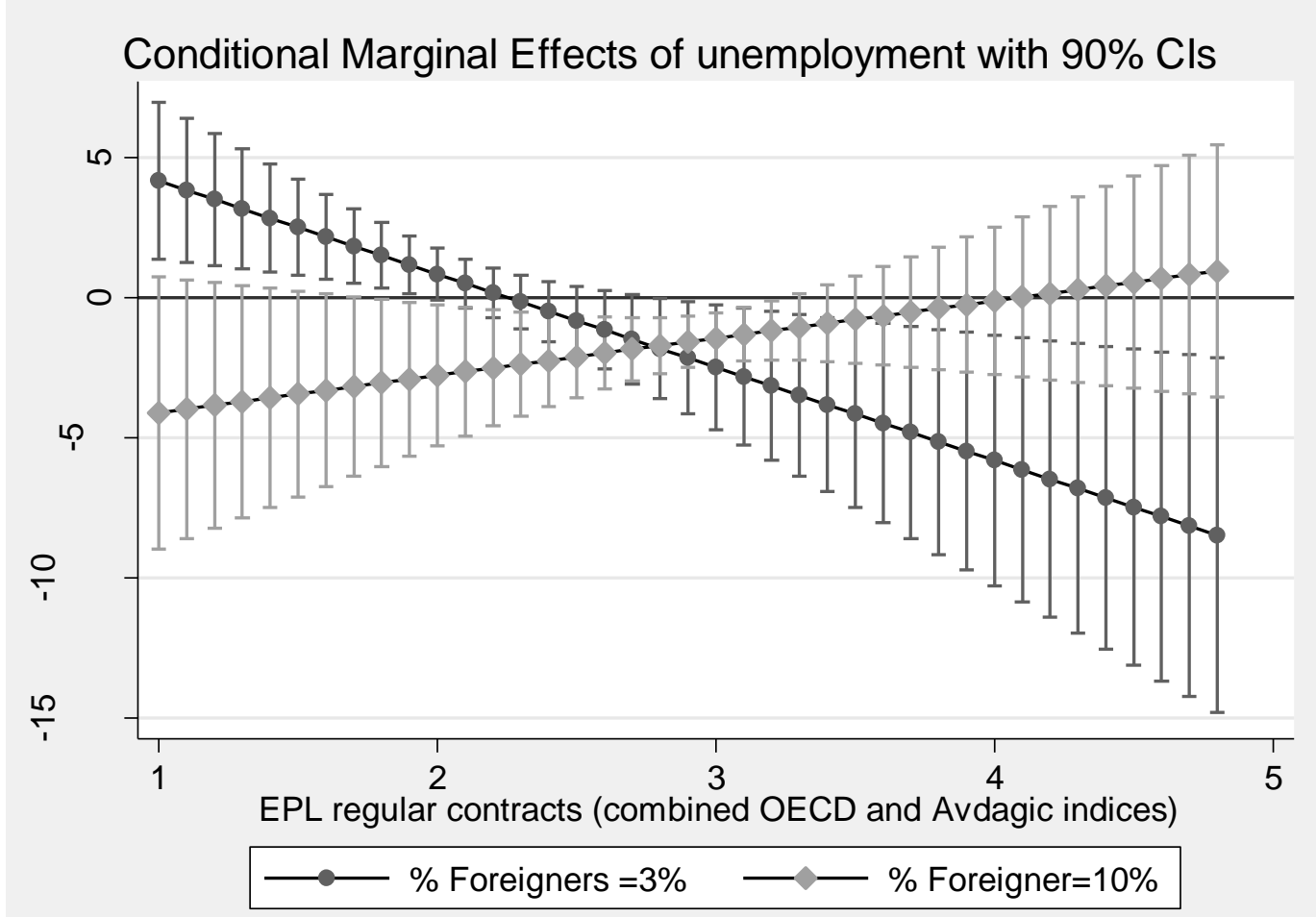


Appendix 1: List of Far right parties in 14 West European and 10 East European countries, per country

\begin{tabular}{|c|c|}
\hline Country & Far right party \\
\hline Austria & Freedom Party (FPÖ) \\
\hline Austria & Alliance for the Future of Austria (BZÖ) \\
\hline Belgium & Democratic Union for the Respect of Labour (UDRT/RAD) \\
\hline Belgium & National Front (FN-NF) \\
\hline Belgium & Flemish Block \\
\hline Bulgaria & $\begin{array}{l}\text { George Day-International Macedonian Revolutionary } \\
\text { Organization (VMRO-Gergiovden) }\end{array}$ \\
\hline Bulgaria & Party Ataka (Nacionalno Obedinenie Ataka) \\
\hline Bulgaria & National Front for the Salvation of Bulgaria (NDSB) \\
\hline Czech Republic & $\begin{array}{l}\text { Rally for the Republic - Republican Party of Czechoslovakia } \\
\text { (Sdruzení Pro Re- publiku - Republikánská Strana } \\
\text { Československa, SPR-RSC) }\end{array}$ \\
\hline Czech Republic & $\begin{array}{l}\text { Sovereignty/Jana Bobošíková Bloc (Suverenita/blok Jany } \\
\text { Bobošiková, SUV) }\end{array}$ \\
\hline Czech Republic & $\begin{array}{l}\text { Dawn of Direct Democracy of Tomio Okamura (Úsvit Prímé } \\
\text { Demokracie Tomia Okamury, Usvit) }\end{array}$ \\
\hline Czech Republic & Party of Free Citizens (Strana svobodných občanů, SSO) \\
\hline Denmark & Danish People's Party (DF) \\
\hline Estonia & Estonian Citizens (Eesti Kodanik) \\
\hline Estonia & $\begin{array}{l}\text { Estonian National Independence Party (Eesti Rahvusliku } \\
\text { Sõltumatuse Partei, ERSP) }\end{array}$ \\
\hline Estonia & Estonian Future Party (Tulevikupartei, TP) \\
\hline Estonia & $\begin{array}{l}\text { Better Estonia + Estonian Citizens (Parem Eesti ja Eesti Kodanik, } \\
P E \& E K \text { ) }\end{array}$ \\
\hline Finland & True Finns (PS) \\
\hline France & Front National (FN) \\
\hline Germany & National Democratic Party (NDP) \\
\hline Germany & Republicans \\
\hline
\end{tabular}




\begin{tabular}{|c|c|}
\hline Germany & Alternative for Germany (AfD) \\
\hline Greece & National Alignment, National Front (EM) \\
\hline Greece & Popular Orthodox Rally (LAOS) \\
\hline Greece & Independent Greeks (ANEL) \\
\hline Greece & Golden Dawn (GD) \\
\hline Hungary & $\begin{array}{l}\text { Hungarian Justice and Life Party (Magyar Igazsag es Élet Partya, } \\
\text { MIÉP) }\end{array}$ \\
\hline Hungary & For the Right Hungary (Jobbik) \\
\hline Ireland & N/A \\
\hline Italy & National Alliance (AN) \\
\hline Italy & Northern League (Lega Nord) \\
\hline Latvia & For Homeland (Fatherland) and Freedom TB \\
\hline Latvia & $\begin{array}{l}\text { Latvian National Independence Movement (Latvijas Nacionālas } \\
\text { Neatkarības Kustība, LNNK) }\end{array}$ \\
\hline Latvia & $\begin{array}{l}\text { People's (National) Movement for Latvia - Siegerist Party } \\
\text { (Tautas Kustība Latvijai - Zigerista Partija, TKL-ZP) }\end{array}$ \\
\hline Latvia & $\begin{array}{l}\text { Alliance for Homeland and Freedom / Latvian National } \\
\text { Independence Movement (TB/LNNK) }\end{array}$ \\
\hline Latvia & $\begin{array}{l}\text { Everything for Latvia/For Fatherland and Freedom/LNNK (Visu } \\
\text { Latvijai/TB/LNNK) (competed in } 2011 \text { under the name National } \\
\text { Union [Nacionālā apvienība „Visu Latvijai!" - „Tēvzemei un } \\
\text { Brīvībai/LNNK], NA) }\end{array}$ \\
\hline Lithuania & $\begin{array}{l}\text { Lithuanian National Party 'Young Lithuania' (Lietuviu Nacionaline } \\
\text { Partija 'JaunojiLietuva', LNP-JL) }\end{array}$ \\
\hline Lithuania & $\begin{array}{l}\text { Lithuanian National Union List [comprised of Lithuanian National } \\
\text { Union and Independent Party] }\end{array}$ \\
\hline Lithuania & Lithuanian National Union and Lithuanian Democratic Party \\
\hline Netherlands & Centre Democrats (CD) \\
\hline Netherlands & List Pim Fortuyn (LPF) \\
\hline Netherlands & Freedom Party (PVV) \\
\hline Norway & Progress Party \\
\hline
\end{tabular}




\begin{tabular}{|c|c|}
\hline Poland & $\begin{array}{l}\text { Confederation for Independent Poland (Konfederacja Polski } \\
\text { Niepodlegtej, KPN) }\end{array}$ \\
\hline Poland & Party X (Partia X) \\
\hline Poland & Movement for Rebuilding Poland (Ruch Odbudowy Polski, ROP) \\
\hline Portugal & N/A \\
\hline Romania & Greater Romania Party (Partidul România Mare) \\
\hline Romania & $\begin{array}{l}\text { Party of National Unity of Romanians (Partidul Unităţii Naţionale } \\
\text { Române PUNR), }\end{array}$ \\
\hline Slovakia & Slovak National Party (Slovenská národná strana, SNS) \\
\hline Slovakia & $\begin{array}{l}\text { Movement for a Democratic Slovakia (Hnutie za demokratické } \\
\text { Slovensko, HZDS, since 2006: L'S-HZDS) }\end{array}$ \\
\hline Slovakia & $\begin{array}{l}\text { The Real Slovak National Party (Pravá Slovenská národná strana, } \\
\text { PSNS) }\end{array}$ \\
\hline Slovakia & Movement for Democracy (Hnutie za demokraciu, HZD) \\
\hline Slovenia & Slovenian National Party (Slovenska Nacionalna Stranka, SNS) \\
\hline Spain & $\begin{array}{l}\text { National Union (also included Falange Espanola, the Alianza } \\
\text { Nacional and other neo-fascist groups) }\end{array}$ \\
\hline Sweden & New Democracy (NYD) \\
\hline Sweden & Sweden Democrats (SD) \\
\hline United Kingdom & United Kingdom Independence Party (UKIP) \\
\hline
\end{tabular}

